\title{
Analysis of Property Tax Revenues Before and During the Covid-19 Pandemic in Sukabumi
}

\author{
Dede Wahidin*, Fitri Mareta, Heliani, Retna Wulandari, Widia Khairunnisa \\ Nusa Putra University, West Java, Indonesia
}

${ }^{*}$ Corresponding author:

E-mail:

dede_wahidin_ak18@nusaputra.ac.id

\begin{abstract}
The problem that occurred during this pandemic, many people were affected by it, including the company so that the community's income was also reduced to the company. This study aims to find out the Income-tax of property in Sukabumi Regency before the existence of Covid-19 and at the time of Covid-19. The method used in this research is a qualitative method with data collection techniques in the form of direct interviews and data collection directly at the Sukabumi District Revenue Agency office. Based on the results of research conducted that the Property Tax Revenues in District Sukabumi did not always reach the target set in the fiscal year. The target is fulfilled every year because of the receivables in the previous year that he withered in the following years as well as during the pandemic covid-19 even though the target of property tax revenues was lowered and given a stimulus to the taxpayer, in October has exceeded the specified target.
\end{abstract}

Keywords: Property tax revenues, covid-19

\section{Introduction}

In general, a State wants to prosper its people but requires considerable funds in building a State that can prosper its people. Indonesia has various revenue sectors including oil and non-oil and gas. One of the tax revenue sectors, which is a supporting sector for the government to realize the plan for the welfare of the people (Wisnumurti et al., 2018).

State revenue from this tax is one of the largest income and very influential in national development. In July 2020, state revenues reached Rp. 922.2 trillion or 54.3 percent of the target of changes in the State Budget in President Rules No. 72 the Year 2020 amounting to Rp. 1,669.9 trillion. Therefore, the tax sector revenues continue to be developed, updated, and refined to improve the prosperity and welfare of the community to realize the role of national development (Agustina et al., 2019).

Tax is one of the main sources of state revenue for national implementation and development, the tax also serves to finance state expenditures such as providing various facilities including educational facilities, health, infrastructure, and other public services. Likewise, the tax system is constantly updated to make it better.

However, at the beginning of March 2020, Indonesia got covid-19 which has a huge impact on the global economy including in the taxation sector, various efforts are made to restore the Indonesian economy, one of which is from property taxes, to stabilize the economy during the covid19 pandemic, to ease the economic burden on the community (Dhajalante et al., 2020).

One of them is in Sukabumi district, Sukabumi Regency Government through Sukabumi regent issued a policy for Property Tax, in a letter issued by Sukabumi Regent No. 973/Kep.686Bapenda/2020 on August 31, 2020, which contains the provision of incentives to taxpayers and the elimination of administrative fines in the form of interest, fines in the form of reductions, and

\section{How to cite:}

Wahidin, D., Mareta, F., Heliani, Wulandari, R., \& Khairunnisa, W. (2021). Analysis of property tax revenues before and during the covid-19 pandemic in Sukabumi. 1' ICEMAC 2020: International Conference on Economics, Management, and Accounting. NST Proceedings. pages 189-195. doi: 10.11594/ nstp.2021.1023 
removing administrative sanctions of interest and fines for taxpayers on arrears in 2015 until 2020. (Sukabumi District Government, 2020)

Based on the fiscal year, namely, from January to December, the target revenue of Property Tax in Sukabumi district in 2019 amounted to IDR 59,913,627,500 with taxpayers as much as $1,205,654$ with the realization in 2019 of IDR 53,640,707,858 with the number of taxpayers $1,110,878$ remaining targets amounting to IDR $6,272,919,642$ with taxpayers 94,776 . As well as the target of Property Tax in 2020 of IDR 75,253,498,902 with a total taxpayer of 1,236,175, but with this pandemic, the target in 2020 is lowered to IDR 51,000,000,000 with a total taxpayer of $1,236,175$.

The problems that occurred during this pandemic were many people who were affected, including the company, so that the community's income also decreased in the company, so that the community's obligation to pay taxes was reduced by obediently paying taxes so that taxpayers did not implement it. their obligation to pay taxes. it can be seen from the comparison of the table of land and building tax income in 2019 and 2020 that there are still many in arrears.

\section{Research Purposes}

1. To know your property tax revenue before the pandemic.

2. To know your property tax revenue after the pandemic.

3. Knowing the efforts of the Sukabumi district government to ease the burden on taxpayers in carrying out their obligations to pay Property Tax.

\section{Literature Review}

\section{Tax}

According to Rochmat Soemitro quoted in the book, Mardiasmo explained that taxes are people's dues for state coffers imposed under the law without obtaining reciprocal services directly used to pay for public expenditures. So, it can be concluded that taxes are coercive and do not directly get reciprocal (counter-achievement).

Based on The Law on Local Taxes and Local Levies year, 2009 Article 1 said that tax is a mandatory contribution to the Region owed by a person or entity that is forceful under the Law, without obtaining direct rewards and used for regional purposes for the maximum prosperity of the people. So, it can be concluded that in the local tax levied by the local government to individuals or entities, which are coercive and do not get reciprocal directly, and used for the benefit of the region.

\section{Property Taxes}

According to Marihot Pahala Siahaan property tax, controlled and or utilized by individuals or entities, except areas used for plantation, forestry, and mining business activities.

Property Tax Object

The imposition of Earth Tax Object and Urban and Rural Buildings are:

1. The neighborhood street, which is located in a block with hotels, factories, and emplacement.

2. Highway

3. Swimming Pool

4. Fancy fence

5. Sports Venues

6. Pier

7. Luxury Garden

8. Oil, water, and gas storage/refineries, oil pipelines

9. Tower 


\section{Not the object of property tax}

On these property taxes, not all are taxed. If it is not taxed if the object of tax meets the provisions that are.

1. Land or buildings used by the government

2. Land or buildings are used for the public interest in various fields, be it in the fields of ibadah, social, health, education, and culture. By not intending to profit on the object of such taxes.

3. Used for graves, historical relics, and so on.

4. Protected forests, nature reserve forests, tourist forests, national parks, development lands that are squeezed by villages, and state lands that have not been burdened with rights.

5. Used by diplomatic representatives and consulates based on reciprocal treatment

6. Used by international institutions established based on financial meter regulations.

\section{Subject and taxpayers}

The object of the tax is a person or entity who has the right to the earth and buildings and benefit the earth and owns controls and benefits the earth, then the proof of ownership is not only payment/payment of taxes only. Thus the subject of tax and taxpayers is to be on the same self.

\section{Basic taxation}

The basis of the taxation is based on the Selling Value of Tax Object, which is the average price obtained from a reasonable buying and selling transaction, the amount of the selling value of this tax object is determined every three years by the Directorate General of Taxation on behalf of the Minister of Finance taking into account the opinion of the Governor / Mayor / Regent who is the local government.

\section{The selling value of the taxable object}

Is the amount of Selling Value of Tax Object where the taxpayer is not owed tax, meaning that if the taxpayer has a tax object but the value is below the then the taxpayer is freed from tax payments.

\section{Tax rate}

The tax rate is determined by the respective local governments, in Sukabumi districts the earth and building tax rates are set as follows, If the selling value of the tax object is up to $1,000,000,000.00$ (one billion rupiahs) then it is set at $0.11 \%$ (zero point eleven percent) per year and if the selling value of the tax object is above IDR 1,000,000,000.- (one billion rupiahs) is set at $0.25 \%$ (zero point twenty-five percent) per year.

\section{Calculations}

The calculation of building earth tax determines the tax payable by multiplying the land and building tax rate based on taxation after deducting is not taxable.

Tax period and when tax is owed

The tax year is a long period that is in 1 (one) calendar year. As well as on taxes owed according to the state of the tax object that is as of January 1.

\section{Tax collection}

In the tax collection can not be or prohibited to be wasted, meaning the process of tax collection activities can not be submitted to the third party. 


\section{Material and Methods}

The method used in this research is entitled Analysis of Land and Building Tax Revenue Before and During the Covid-19 Pandemic in Sukabumi Regency, this is a qualitative method, a qualitative research method is the collection of data in a natural atmosphere to interpret the phenomena that occurred in 2019 where the researcher is the key instrument. , by collecting and using interview techniques, data collection at the Sukabumi Regency Revenue Service, this research was conducted on November 11, 2020

\section{Results and Discussion}

\section{Property Tax before the covid-19 pandemic in Sukabumi}

Based on the collection of taxes collected by the central and local governments, and in its implementing rules implemented by the Directorate General of Taxes under the Ministry of Finance of the Republic of Indonesia with the aim of financing state households and based on law No. 28 of 2009. The region is a unity of the legal community that has the boundaries of the territory authorized to regulate and manage public affairs kat in the system of the Unitary State of the Republic of Indonesia with the boundaries of the territory, each region can be creative to obtain a source of revenue to finance every regional expenditure, one of which is property tax. Property Tax has been determined to be one of the district/city taxes, if a district/city has no local regulations on Property Tax then the collection becomes the authority of the central government. However, on June 29, 2012, Sukabumi regent set local regulation number 23 of 2012 on Property Tax for Sukabumi area. (Siahaan, 2016).

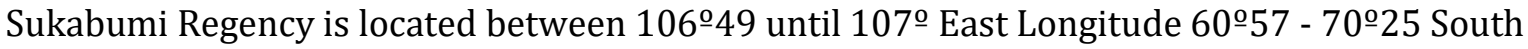
Latitude with the northern boundary with Bogor Regency, South by Indonesian Ocean, West with Lebak Regency, and East with Cianjur Regency. Sukabumi Regency is the second-largest regency in Java after the Banyuwangi regency and the largest regency in West Java, with an area of 4,162 $\mathrm{km} 2$, consisting of 47 sub-districts and 364 villages and 3 villages. (Provincial Government Jabar)

Economic growth in Sukabumi Regency in 2019 reached 5.75 percent, based on data obtained from the Central Statistics Agency Sukabumi regency, during the last five years the highest economic growth occurred in 2016 at 5.85 percent and the lowest of 4.91 percent in 2015. Meanwhile, in 2019, the economic growth rate reached 5.75 percent.

Sukabumi Regency government continues to innovate to increase revenues in the local tax sector, one of which is in the property tax sector, Sukabumi district government slices the payment system of Earth and Rural Buildings and Urban Online Barcode-based to make it easier for people in the information of local tax payments thus the Sukabumi district government insure ginkan (Sukabumi Kab. 2019).

Property Tax Target has a provision dan realization of fiscal year 2019, the target of Property Tax of IDR 59,913,627,500 with taxpayers 1,205,654 with the realization of income of IDR $53,560,707,858$ with taxpayers $1,110,878$, with the remaining realization of IDR 5,272,919,642 with taxpayers 94,776. so according to Mr. Robes of the Property Tax Collection and Management section, each year on the earth and building taxes of these 47 subdistricts is not always paid off, with the remaining realization suspended into receivables in 2019, shrinking the receivables that at least every year there must be a payment. So, every year, this collateral is always fulfilled even though it does not reach the target because the receivables in the previous year cover the target in the following year. 
Table 1. The realization year 2019

\begin{tabular}{|c|c|c|c|c|c|c|c|c|}
\hline \multirow{2}{*}{ NO } & \multirow{2}{*}{ Sub-District } & \multicolumn{2}{|r|}{ Provisions } & \multicolumn{3}{|c|}{$\begin{array}{l}\text { Realization Until This } \\
\text { Month }\end{array}$} & \multicolumn{2}{|c|}{ Rest of The Provisions } \\
\hline & & WP & $\mathbf{R P}$ & WP & & $\mathbf{R P}$ & WP & $\mathbf{R P}$ \\
\hline 1 & WARUNGKIARA & 25757 & 779.737 .788 & 23473 & $\mathrm{Rp}$ & 727.256 .446 & 2284 & 52.481 .342 \\
\hline 2 & PABUARAN & 36965 & 897.636 .687 & 28854 & $\mathrm{Rp}$ & 712.056 .649 & 8111 & Rp 185.580.038 \\
\hline 3 & NYALINDUNG & 34571 & 925.687 .454 & 34432 & $\mathrm{Rp}$ & 874.095 .715 & 139 & $\mathrm{Rp} \quad 51.591 .739$ \\
\hline 4 & N A G R A K & 37419 & Rp 1.683.652.770 & 32651 & $\mathrm{Rp}$ & .456 .004 .287 & 4768 & Rp 227.648.483 \\
\hline 5 & LENGKONG & 20769 & $\mathrm{Rp} \quad 852.873 .417$ & 19791 & $\mathrm{Rp}$ & 803.271 .015 & 978 & $\mathrm{Rp} \quad 49.602 .402$ \\
\hline 6 & KEBONPEDES & 12149 & 601.335 .659 & 11415 & $\mathrm{Rp}$ & 551.587 .004 & 734 & 49.748 .655 \\
\hline 7 & KALIBUNDER & 27260 & 656.197 .884 & 27260 & $\mathrm{Rp}$ & 665.450 .487 & 0 & - \\
\hline 8 & KALAPANUNGGAL & 24160 & 661.532 .783 & 24159 & $\mathrm{Rp}$ & 662.985 .351 & 0 & - \\
\hline 9 & KADUDAMPIT & 20037 & 892.602 .454 & 20030 & $\mathrm{Rp}$ & 867.086 .821 & 7 & 25.515 .633 \\
\hline 10 & KABANDUNGAN & 19521 & 344.491 .456 & 19494 & $\mathrm{Rp}$ & 329.631 .157 & 27 & 14.860 .299 \\
\hline 11 & PALABUHANRATU & 43949 & Rp 4.103.766.273 & 35011 & $\mathrm{Rp}$ & .267 .493 .714 & 8938 & Rp 836.272.559 \\
\hline 12 & PARAKANSALAK & 15684 & $\mathrm{Rp} \quad 600.860 .513$ & 15683 & $\mathrm{Rp}$ & 599.711 .146 & 1 & $\mathrm{Rp} \quad 1.149 .367$ \\
\hline 13 & PARUNGKUDA & 21240 & Rp 2.663.490.778 & 19452 & $\mathrm{Rp}$ & .466 .782 .742 & 1788 & Rp 196.708.036 \\
\hline 14 & WALURAN & 14488 & $\mathrm{Rp} \quad 390.109 .922$ & 14485 & $\mathrm{Rp}$ & 388.723 .735 & 3 & $\mathrm{Rp} \quad 1.386 .187$ \\
\hline 15 & TEGALBULEUD & 23386 & $\mathrm{Rp} \quad 996.913 .655$ & 23383 & $\mathrm{Rp}$ & 994.358 .629 & 3 & 2.555 .026 \\
\hline 16 & SURADE & 52874 & Rp 1.029.492.260 & 49564 & $\mathrm{Rp}$ & 959.305 .499 & 3310 & 70.186 .761 \\
\hline 17 & SUKARAJA & 30919 & Rp 2.173.412.302 & 21677 & $\mathrm{Rp}$ & .657 .452 .503 & 9242 & Rp 515.959.799 \\
\hline 18 & SUKALARANG & 16387 & Rp 2.151.197.871 & 13364 & $\mathrm{Rp}$ & .987 .613 .269 & 3023 & Rp 163.584.602 \\
\hline 19 & SUKABUMI & 16104 & Rp 1.836.043.465 & 11585 & $\mathrm{Rp}$ & .444 .593 .520 & 4519 & Rp 391.449.945 \\
\hline 20 & SIMPENAN & 28530 & $\mathrm{Rp} \quad 900.693 .699$ & 27496 & $\mathrm{Rp}$ & 692.290 .185 & 1034 & Rp 208.403.514 \\
\hline 21 & SAGARANTEN & 40571 & 811.325 .681 & 40379 & $\mathrm{Rp}$ & 807.791 .925 & 192 & $\mathrm{Rp} \quad 3.533 .756$ \\
\hline 22 & PURABAYA & 28060 & 586.928 .001 & 27658 & $\mathrm{Rp}$ & 578.508 .149 & 402 & 8.419 .852 \\
\hline 23 & JAMPANGTENGAH & 41281 & Rp 1.313.842.200 & 38227 & $\mathrm{Rp}$ & .172 .201 .969 & 3054 & Rp 141.640.231 \\
\hline 24 & JAMPANGKULON & 34428 & $\mathrm{Rp} \quad 664.064 .493$ & 34355 & $\mathrm{Rp}$ & 665.210 .963 & 0 & - \\
\hline 25 & GUNUNGGURUH & 18046 & $\mathrm{Rp} \quad 867.168 .324$ & 15823 & $\mathrm{Rp}$ & 749.571 .657 & 2223 & Rp 117.596.667 \\
\hline 26 & CICANTAYAN & 24000 & Rp 1.295.173.184 & 23858 & $\mathrm{Rp}$ & .172 .170 .334 & 142 & Rp 123.002.850 \\
\hline 27 & CIBITUNG & 17859 & $\mathrm{Rp} \quad 248.855 .463$ & 17151 & $\mathrm{Rp}$ & 237.490 .947 & 708 & $\mathrm{Rp} \quad 11.364 .516$ \\
\hline 28 & CIBADAK & 29456 & Rp 2.916.708.979 & 25379 & $\mathrm{Rp}$ & .574 .527 .254 & 4077 & Rp 342.181.725 \\
\hline 29 & CIAMBAR & 16812 & $\mathrm{Rp} \quad 936.260 .806$ & 16633 & $\mathrm{Rp}$ & 929.366 .048 & 179 & $\mathrm{Rp} \quad 6.894 .758$ \\
\hline 30 & CARINGIN & 21487 & 694.937 .501 & 21153 & $\mathrm{Rp}$ & 681.280 .572 & 334 & 13.656 .929 \\
\hline 31 & C I R A C A P & 30381 & 683.695 .002 & 29271 & $\mathrm{Rp}$ & 659.895 .471 & 1110 & 23.799 .531 \\
\hline 32 & C I D O L O G & 16825 & $\mathrm{Rp} \quad 509.511 .397$ & 16815 & $\mathrm{Rp}$ & 507.305 .116 & 10 & Rp $\quad 2.206 .281$ \\
\hline 33 & C I D A H U & 25165 & Rp 1.744.566.953 & 22841 & $\mathrm{Rp}$ & .461 .417 .858 & 2324 & Rp 283.149.095 \\
\hline 34 & BOJONGGENTENG & 11920 & $\mathrm{Rp} \quad 527.974 .088$ & 11489 & $\mathrm{Rp}$ & 489.420 .867 & 431 & $\mathrm{Rp} \quad 38.553 .221$ \\
\hline 35 & CICURUG & 33656 & Rp 6.749.380.188 & 29895 & $\mathrm{Rp}$ & .130 .623 .615 & 3761 & Rp 618.756.573 \\
\hline 36 & CIDADAP & 11383 & $\mathrm{Rp} \quad 334.122 .592$ & 9415 & $\mathrm{Rp}$ & 282.507 .687 & 1968 & $\mathrm{Rp} \quad 51.614 .905$ \\
\hline 37 & CIEMAS & 36855 & Rp 1.319.112.709 & 32549 & $\mathrm{Rp}$ & .172 .775 .729 & 4306 & Rp 146.336.980 \\
\hline 38 & GEGERBITUNG & 20360 & Rp $\quad 739.247 .852$ & 20344 & $\mathrm{Rp}$ & 702.977 .528 & 16 & Rp $\quad 36.270 .324$ \\
\hline 39 & CURUGKEMBAR & 23986 & $\mathrm{Rp} \quad 469.655 .926$ & 23985 & $\mathrm{Rp}$ & 471.617 .951 & 0 & - \\
\hline 40 & CISOLOK & 33215 & Rp 1.250.457.776 & 29776 & $\mathrm{Rp}$ & .034 .168 .415 & 3439 & Rp 216.289.361 \\
\hline 41 & CISAAT & 33234 & Rp 2.258.109.491 & 29934 & $\operatorname{Rp} 2$ & .046 .031 .806 & 3300 & Rp 212.077.685 \\
\hline 42 & CIREUNGHAS & 17656 & $\mathrm{Rp} \quad 734.323 .575$ & 10801 & $\mathrm{Rp}$ & 389.742 .703 & 6855 & Rp 344.580.872 \\
\hline 43 & CIMANGGU & 14373 & Rp $\quad 240.621 .190$ & 14373 & $\mathrm{Rp}$ & 240.621 .190 & 0 & $\mathrm{Rp} \quad-$ \\
\hline 44 & CIKIDANG & 19392 & Rp 1.011.314.151 & 17356 & $\mathrm{Rp}$ & 869.119 .443 & 2036 & Rp 142.194.708 \\
\hline 45 & CIKEMBAR & 37493 & Rp 4.413.578.556 & 37005 & $\mathrm{Rp}$ & .253 .130 .701 & 488 & Rp 160.447.855 \\
\hline 46 & СІКАКАК & 21750 & $\mathrm{Rp} \quad 890.295 .712$ & 21464 & $\mathrm{Rp}$ & 806.980 .063 & 286 & $\mathrm{Rp} \quad 83.315 .649$ \\
\hline 47 & BANTARGADUNG & 23841 & $\mathrm{Rp} \quad 560.666 .620$ & 19690 & $\mathrm{Rp}$ & 446.502 .023 & 4151 & Rp 114.164.597 \\
\hline & Total & $\begin{array}{l}1205 \\
654\end{array}$ & Rp.59.913.627.500 & 1110878 & $\operatorname{Rp} 5$ & .640 .707 .858 & 94776 & Rp 6.272.919.642 \\
\hline
\end{tabular}




\section{Property tax at the time of the covid-19 pandemic in Sukabumi.}

In 2020, the covid-19 pandemic will not only affect the economy, but also affect the taxation sector, one of which is on property taxes, the target of Property Tax in 2020is purely set at IDR $75,253,498,902$ with 1,236 taxpayers, but in a pandemic, the government provided the stimulus and lowered the target to 51,000,000,000 with the same number of the taxpayer. At the end of October, the realization in property taxes reached 56,124,692,969.

Table 2. Realization year 2020

\begin{tabular}{|c|c|c|c|c|c|c|c|c|c|c|}
\hline \multirow[t]{2}{*}{ NO } & \multirow[t]{2}{*}{ SUB-DISTRICT } & \multicolumn{3}{|c|}{ PROVISIONS } & \multicolumn{3}{|c|}{$\begin{array}{l}\text { REALIZATION until THIS } \\
\text { MONTH }\end{array}$} & \multicolumn{3}{|c|}{$\begin{array}{l}\text { REST OF THE PROVI- } \\
\text { SIONS }\end{array}$} \\
\hline & & WP & & RP & WP & & $\mathbf{R P}$ & WP & & RP \\
\hline 1 & WARUNGKIARA & 25859 & $\mathrm{Rp}$ & 1.077 .144 .854 & 18573 & $\mathrm{Rp}$ & 811.534 .939 & 7286 & $\mathrm{Rp}$ & 265.609 .915 \\
\hline 2 & PABUARAN & 36859 & $\mathrm{Rp}$ & 1.200 .557 .251 & 25243 & $\mathrm{Rp}$ & 754.667 .529 & 11616 & $\mathrm{Rp}$ & 445.889 .722 \\
\hline 3 & NYALINDUNG & 34533 & $\mathrm{Rp}$ & 1.361 .898 .356 & 31441 & $\mathrm{Rp}$ & .172 .475 .483 & 3092 & $\mathrm{Rp}$ & 189.422 .873 \\
\hline 4 & N A G R A K & 37505 & $\mathrm{Rp}$ & 2.180 .290 .854 & 29368 & $\mathrm{Rp}$ & .737 .788 .156 & 8137 & $\mathrm{Rp}$ & 442.502 .698 \\
\hline 5 & LENGKONG & 20738 & $\mathrm{Rp}$ & 879.507.764 & 13328 & $\mathrm{Rp}$ & 596.438 .516 & 7410 & $\mathrm{Rp}$ & 283.069 .248 \\
\hline 6 & KEBONPEDES & 12077 & $\mathrm{Rp}$ & 780.609 .091 & 9723 & $\mathrm{Rp}$ & 597.805 .585 & 2354 & $\mathrm{Rp}$ & 182.803 .506 \\
\hline 7 & KALIBUNDER & 28907 & $\mathrm{Rp}$ & 706.393 .132 & 19125 & $\mathrm{Rp}$ & 445.440 .159 & 9782 & $\mathrm{Rp}$ & 260.952 .973 \\
\hline 8 & KALAPANUNGGAL & 24276 & $\mathrm{Rp}$ & 887.023 .983 & 24265 & $\mathrm{Rp}$ & 875.680 .679 & 11 & $\mathrm{Rp}$ & 11.343 .304 \\
\hline 9 & KADUDAMPIT & 20084 & $\mathrm{Rp}$ & 1.177.389.598 & 17465 & $\mathrm{Rp}$ & 980.324 .003 & 2619 & $\mathrm{Rp}$ & 197.065 .595 \\
\hline 10 & KABANDUNGAN & 19847 & $\mathrm{Rp}$ & 492.344 .896 & 14357 & $\mathrm{Rp}$ & 315.186 .209 & 5490 & $\mathrm{Rp}$ & 177.158.687 \\
\hline 11 & PALABUHANRATU & 44193 & $\mathrm{Rp}$ & 4.965.659.278 & 21152 & $\mathrm{Rp}$ & .505 .328 .110 & 23041 & $\mathrm{Rp}$ & .460 .331 .168 \\
\hline 12 & PARAKANSALAK & 15826 & $\mathrm{Rp}$ & 801.467 .923 & 14732 & $\mathrm{Rp}$ & 712.200 .711 & 1094 & $\mathrm{Rp}$ & 89.267.212 \\
\hline 13 & PARUNGKUDA & 21702 & $\mathrm{Rp}$ & 2.870 .363 .447 & 16124 & $\mathrm{Rp}$ & .303 .906 .141 & 5578 & $\mathrm{Rp}$ & 566.457 .306 \\
\hline 14 & WALURAN & 14869 & $\mathrm{Rp}$ & 545.530 .020 & 10128 & $\mathrm{Rp}$ & 316.323.295 & 4741 & $\mathrm{Rp}$ & 229.206 .725 \\
\hline 15 & TEGALBULEUD & 34501 & $\mathrm{Rp}$ & 1.501.175.715 & 20129 & $\mathrm{Rp}$ & 664.316 .929 & 14372 & $\mathrm{Rp}$ & 836.858 .786 \\
\hline 16 & SURADE & 53212 & $\mathrm{Rp}$ & 1.423 .878 .265 & 36259 & $\mathrm{Rp}$ & 760.554 .936 & 16953 & $\mathrm{Rp}$ & 663.323 .329 \\
\hline 17 & SUKARAJA & 32137 & $\mathrm{Rp}$ & 2.830 .847 .886 & 16700 & $\mathrm{Rp}$ & .766 .703 .862 & 15437 & & .064 .144 .024 \\
\hline 18 & SUKALARANG & 16504 & $\mathrm{Rp}$ & 2.622.223.572 & 11296 & $\mathrm{Rp}$ & .163 .782 .780 & 5208 & $\mathrm{Rp}$ & 458.440 .792 \\
\hline 19 & SUKABUMI & 16249 & $\mathrm{Rp}$ & 2.246 .834 .678 & 10467 & $\mathrm{Rp}$ & .427 .830 .641 & 5782 & $\mathrm{Rp}$ & 819.004 .037 \\
\hline 20 & SIMPENAN & 28791 & $\mathrm{Rp}$ & 1.180 .170 .777 & 23826 & $\mathrm{Rp}$ & 754.020 .044 & 4965 & $\mathrm{Rp}$ & 426.150 .733 \\
\hline 21 & SAGARANTEN & 40672 & $\mathrm{Rp}$ & 1.284 .313 .012 & 30847 & $\mathrm{Rp}$ & 967.009 .524 & 9825 & $\mathrm{Rp}$ & 317.303 .488 \\
\hline 22 & PURABAYA & 28112 & $\mathrm{Rp}$ & 818.293.956 & 24730 & $\mathrm{Rp}$ & 732.722 .245 & 3382 & $\mathrm{Rp}$ & 85.571 .711 \\
\hline 23 & JAMPANGTENGAH & 41374 & $\mathrm{Rp}$ & 1.770 .830 .577 & 32123 & $\mathrm{Rp}$ & .312 .172 .065 & 9251 & $\mathrm{Rp}$ & 458.658 .512 \\
\hline 24 & JAMPANGKULON & 34495 & $\mathrm{Rp}$ & 919.140 .075 & 34494 & $\mathrm{Rp}$ & 915.843 .915 & 1 & $\mathrm{Rp}$ & 3.296 .160 \\
\hline 25 & GUNUNGGURUH & 18780 & $\mathrm{Rp}$ & 1.258 .886 .820 & 14062 & $\mathrm{Rp}$ & 965.722 .916 & 4718 & $\mathrm{Rp}$ & 293.163 .904 \\
\hline 26 & CICANTAYAN & 24282 & $\mathrm{Rp}$ & 1.478.737.347 & 16532 & $\mathrm{Rp}$ & .042 .431 .366 & 7750 & $\mathrm{Rp}$ & 436.305 .981 \\
\hline 27 & CIBITUNG & 26682 & $\mathrm{Rp}$ & 700.185 .831 & 18390 & $\mathrm{Rp}$ & 471.375 .820 & 8292 & $\mathrm{Rp}$ & 228.810 .011 \\
\hline 28 & CIBADAK & 29977 & $\mathrm{Rp}$ & 3.308.391.280 & 18882 & $\mathrm{Rp}$ & .402 .356 .999 & 11095 & $\mathrm{Rp}$ & 906.034 .281 \\
\hline 29 & CIAMBAR & 16844 & $\mathrm{Rp}$ & 1.174 .255 .811 & 15245 & $\mathrm{Rp}$ & 572.512 .000 & 1599 & $\mathrm{Rp}$ & 601.743 .811 \\
\hline 30 & CARINGIN & 21513 & $\mathrm{Rp}$ & 924.079 .696 & 13646 & $\mathrm{Rp}$ & 629.795 .411 & 7867 & $\mathrm{Rp}$ & 294.284 .285 \\
\hline 31 & C I R A C A P & 30274 & $\mathrm{Rp}$ & 951.786 .046 & 25434 & $\mathrm{Rp}$ & 828.439 .853 & 4840 & $\mathrm{Rp}$ & 123.346 .193 \\
\hline 32 & C I D O L O G & 16744 & $\mathrm{Rp}$ & 688.892 .683 & 16740 & $\mathrm{Rp}$ & 623.869 .357 & 4 & $\mathrm{Rp}$ & 65.023 .326 \\
\hline 33 & C I D A H U & 26098 & $\mathrm{Rp}$ & 2.113.485.841 & 15651 & $\mathrm{Rp}$ & .476 .493 .596 & 10447 & $\mathrm{Rp}$ & 636.992 .245 \\
\hline 34 & BOJONGGENTENG & 11947 & $\mathrm{Rp}$ & 693.247 .352 & 11930 & $\mathrm{Rp}$ & 639.946 .254 & 17 & $\mathrm{Rp}$ & 53.301 .098 \\
\hline 35 & CICURUG & 34244 & $\mathrm{Rp}$ & 7.328.776.894 & 19901 & $\mathrm{Rp}$ & .707 .786 .300 & 14343 & $\mathrm{Rp}$ & .620 .990 .594 \\
\hline 36 & CIDADAP & 11369 & $\mathrm{Rp}$ & 448.405 .884 & 6114 & $\mathrm{Rp}$ & 214.442 .741 & 5255 & $\mathrm{Rp}$ & 233.963 .143 \\
\hline 37 & CIEMAS & 37014 & $\mathrm{Rp}$ & 1.793 .719 .360 & 27587 & $\mathrm{Rp}$ & .216 .755 .432 & 9427 & $\mathrm{Rp}$ & 576.963 .928 \\
\hline 38 & GEGERBITUNG & 20470 & $\mathrm{Rp}$ & 1.048 .236 .598 & 20449 & $\mathrm{Rp}$ & 961.717 .050 & 21 & $\mathrm{Rp}$ & 86.519 .548 \\
\hline 39 & CURUGKEMBAR & 24018 & $\mathrm{Rp}$ & 659.558 .127 & 18968 & $\mathrm{Rp}$ & 500.651 .271 & 5050 & $\mathrm{Rp}$ & 158.906 .856 \\
\hline 40 & CISOLOK & 33523 & $\mathrm{Rp}$ & 1.728 .918 .228 & 26301 & $\mathrm{Rp}$ & .239 .505 .925 & 7222 & $\mathrm{Rp}$ & 489.412 .303 \\
\hline
\end{tabular}

To be continued 


\begin{tabular}{|c|c|c|c|c|c|c|c|c|c|c|}
\hline 41 & CISAAT & 33449 & $\mathrm{Rp}$ & 2.571 .856 .963 & 24100 & \multicolumn{2}{|c|}{ Rp 1.976.404.404 } & 9349 & $\mathrm{Rp}$ & 595.452 .559 \\
\hline 42 & CIREUNGHAS & 17716 & $\mathrm{Rp}$ & 984.530 .285 & 10790 & $\mathrm{Rp}$ & 494.216 .726 & 6926 & $\mathrm{Rp}$ & 490.313 .559 \\
\hline 43 & CIMANGGU & 14410 & $\mathrm{Rp}$ & 335.194 .376 & 14410 & $\mathrm{Rp}$ & 335.194 .376 & 0 & \multicolumn{2}{|c|}{$\mathrm{Rp}$} \\
\hline 44 & CIKIDANG & 19694 & $\mathrm{Rp}$ & 1.411 .443 .833 & 16348 & \multicolumn{2}{|c|}{ Rp 1.144.836.766 } & 3346 & \multicolumn{2}{|c|}{ Rp266.607.067 } \\
\hline 45 & CIKEMBAR & 37960 & $\mathrm{Rp}$ & 5.215 .134 .176 & 30525 & \multicolumn{2}{|c|}{ Rp 4.743.677.168 } & 7435 & \multicolumn{2}{|c|}{$\mathrm{Rp} 471.457 .008$} \\
\hline 46 & CIKAKАK & 21883 & $\mathrm{Rp}$ & 1.114 .108 .814 & 19756 & $\mathrm{Rp}$ & 962.005 .554 & 2127 & \multicolumn{2}{|c|}{ Rp 152.103.260 } \\
\hline 47 & BANTARGADUNG & 23962 & $\mathrm{Rp}$ & 797.777.697 & 10937 & $\mathrm{Rp}$ & 384.499 .228 & 13025 & \multicolumn{2}{|c|}{ Rp 413.278.469 } \\
\hline & Total & $\begin{array}{l}12361 \\
75 \\
\end{array}$ & Rp 75 & 5.253 .498 .902 & $\begin{array}{l}91859 \\
3 \\
\end{array}$ & \multicolumn{3}{|c|}{ Rp 56.124.692.969317582 } & \multicolumn{2}{|c|}{ Rp 19.128.805.933 } \\
\hline
\end{tabular}

The efforts of the Sukabumi Regency government in easing the burden on the people of Sukabumi Regency.

To ease the economic burden on the community, the Regent of Sukabumi issued Decree No. 973/Kep.686-Bapenda/2020 concerning Intensive Provision to Taxpayers and Elimination of Administrative Fines in the Form of Interest, Fines for Taxpayers on Local Tax Arrears in the form of deduction and removing administrative interest sanctions and fines for taxpayers on arrears from 2015 to 2020.

1. As of May 1, June, July, August, there was a stimulus of $20 \%$

2. However, on September 1-9, there was no stimulus, but on September 10, there was the stimulus in commemoration of the anniversary of Sukabumi district.

3. In October, Stimulus was given $15 \%$

4. In November, a stimulus of $10 \%$ was given

5. In December, a stimulus of $5 \%$ was provided

6. And sanctions/fines are issued that are late to make payments.

\section{Conclusion}

It can be concluded that the Property Tax in Sukabumi district does not always reach the target set in the fiscal year but is always met every year, similarly, pandemic the government provides relief to taxpayers by providing stimulus and lowering the pure target in 2020, from IDR $75,253,498,902$ to $51,000,000,000$, but in October the target of property tax has exceeded the target to IDR 56,124,692,969. With the COVID-19 pandemic, the government has provided relief to taxpayers by providing stimulus and lowering the pure target in 2020, from IDR $75,253,498,902$ to $51,000,000,000$, however in October the property tax target has exceeded the target to IDR 56,124,692,969. With the stimulus, it will ease the burden of paying land and building taxes for the community because of the reduction.

\section{References}

Agustina, M. D. P., Budhi, M. K. S., Utama, M. S., \& Yasa, I. G. W. m. (2019). The influence of government role, community participation and social capital on the quality of destination and community welfare in the tourism village of badung regency province of Bali. Russian Journal of Agricultural and Socio-Economic Sciences, 92(8):235-251. DOI:10.18551/rjoas.2019-08.26

Djalante, R., Lassa, J., Setiamarga, D., Sudjatma, A., Indrawan, M., Haryanto, B., Mahfud, X., Sinapoy, M. S., Djalante, S., Rafliana, I., Gunawan, L. A., Surtiari, G. A. K., \& Warsilah, P-H. (2020). Review and analysis of current responses to COVID-19 in Indonesia: Period of January to March 2020. Progress in Disaster Science, 6(2020), 100091.

Provincial Government of West Java. Profile of Sukabumi Regency. Retrieved: https://jabarprov.go.id/index.php/pages/id/1042 ( 25 November 2020)

Siahaan, M. P. (2016). Local taxes and levies. Jakarta: PT Raja Grafindo Persada

Wisnumurti, A. A. G. O., Darma, I. K. D., \& Suasih, N. N. R. (2018). Government policy of indonesia to managing demographic bonus and creating Indonesia Gold in 2045. IOSR Journal of Humanities And Social Science (IOSR-JHSS), 23(1), 23-34. 